\title{
Air Quality Changes in Ukraine during the April 2020 Wildfire Event
}

\author{
Mykhailo Savenets ${ }^{\mathrm{A}^{*}}$, Volodymyr Osadchyi ${ }^{\mathrm{A}}$, Andrii Oreshchenko ${ }^{\mathrm{A}}$, Larysa Pysarenko ${ }^{\mathrm{A}}$ \\ Received: July 18, 2020 | Revised: November 02, 2020 | Accepted: November 16, 2020 \\ doi: 10.5937/gp24-27436
}

\begin{abstract}
The paper analyzes air quality changes in Ukraine during a wildfire event in April 2020 and a dust storm episode during the $16^{\text {th }}$ of April 2020. The wildfire event contained two episodes of active fires and huge pollutants' emission: 4-14 April and 16-21 April, respectively. Using the Sentinel-5P data of CO and $\mathrm{NO}_{2}$ column number density and ground-based measurements, there was estimated air quality deterioration. Advection of polluted air masses and analysis of affected territories were made in combination with a web-based HYSPLIT model. Satellite data described air quality changes better than in-situ measurements. Data intercomparison showed better coincidence in regions that were not affected by wildfire emissions. The paper described the dust storm event based on absorbing aerosol index (AAI) data that occurred between two wildfire episodes.
\end{abstract}

Keywords: wildfire; air quality; carbon monoxide; nitrogen dioxide; dust storm; trajectory

\section{Introduction}

Frequent wildfires and "traditional" agricultural open burning are among the most challenging problems in Ukraine. In recent years, natural fire danger increased due to climate changes in the region (Balabukh \& Malytska, 2017). As a result, lots of man-made "controlled" fires on agricultural fields are turning to uncontrolled wildfires. Each of these fires emits a huge amount of combustion products into the atmosphere that negatively influences human health. Carbon monoxide $(\mathrm{CO})$, nitrogen oxides $\left(\mathrm{NO}_{\mathrm{X}}\right)$, particulate matter (PM), including black carbon (BC), and volatile organic compounds (VOC) are among the pollutants that impact air quality (Knorr et al., 2017; Langmann et al., 2009). Moreover, wildfires become a significant contributor to climate change due to emitting greenhouse gases such as carbon dioxide (CO2) and methane (CH4) (Doerr \& Santin, 2016).

Air quality changes under the influence of wildfire events require a complex approach for data analysis and research methods involvement. Usage of only ground-based data cannot identify the real consequences of pollutants' emission. In the case of the Ukrainian measurement network, there are two main problems. The first one is connected with the location of monitoring stations, which are appropriate only for analysis of urban anthropogenic emissions. As wildfires occur in remote regions, available stations rarely allow providing an accurate warning for the population. Moreover, it could be done only in the case of polluted masses advection toward the affected city. The second problem is spatial heterogeneity of the pollutants' distribution, and there are no background monitoring stations in Ukraine. A national air quality network was developed in the former Soviet Union several decades ago, where monitoring sites were located close to the main anthropogenic emission sources. As a result, all stations of the air quality network could not be considered as the background ones. Nowadays, the first steps have been done for changing national regulations and establishing background

\footnotetext{
A Ukrainian Hydrometeorological Institute, 37 Nauky Prospect, 03028, Kyiv, Ukraine; savenets@uhmi.org.ua; osad@uhmi.org.ua; logograd@ukr.net; larpys@uhmi.org.ua

${ }^{*}$ Corresponding author: Mykhailo Savenets; e-mail: savenets@uhmi.org.ua
} 
stations for air quality monitoring and management in the future. Hence, at the very close distances from in-situ observations (which show only huge anthropogenic pollution), there is no statistically reliable data, even after extra-/ interpolation. The main solution for both problems is the integration of satellite data and atmospheric modeling.

Remote sensing provides us with great spatial coverage, giving a day-to-day global view of air pollution, where the most precise spatial resolution reaches $7 \times 7 \mathrm{~km}$ for Sentinel-5P satellite and the TROPOspheric Monitoring Instrument (TROPOMI) on it (Internet 1). During the wildfire events, it becomes possible for air quality analysis over remote regions (Sunar \& Özkan, 2001) and compare results with background values. Mainly, two species (column number densities) are taken from satellite measurement for analysis of air pollution during wildfires: $\mathrm{CO}$ (Borsdorff et al., 2018a; Deeter et al., 2018; Turquety et al., 2007) and NO2 (Mebust et al., 2011; Schreier et al., 2015). Satellite data could be used for the estimation of burned products emission (Adams et al., 2019) and were implemented in the number of air quality applications (Levelt et al., 2018). TROPOMI data have already recommended itself for the purpose of air quality monitoring (Borsdorff et al., 2018b; Griffin et al., 2020; Kaplan \& Avdan, 2020; Savenets et al, 2019; Theys et al., 2019).

Of course, satellite observations have some disadvantages (Brennan et al., 2019; Duncan et al, 2014; Engel-Cox et al, 2004; Ialongo et al., 2020; Voulgarakis \& Field, 2015), e.g., an impossibility for the recalculation to near-ground values, complex atmospheric correction, uncertainties for burned area estimation, tempo$\mathrm{ral} / \mathrm{spatial}$ resolution, etc. However, modern satellites give a good qualitative picture of air quality changes.

Some disadvantages of remote sensing could be solved using atmospheric modeling, that also became very popular for studying wildfire events (Coen et al., 2013; Eastham \& Jacob, 2017; Heilman et al., 2014;
Lazaridis, et al., 2008; Lutsch et al., 2019), including the Ukrainian territory (Galytska et al, 2018; Mahura et al, 2019). For different kinds of events that are accompanied by pollutants' emission, the Hybrid Single-Particle Lagrangian Integrated Trajectory model (HYSPLIT) (Internet 2; Rolph et al, 2017; Stein et al, 2015) is popular for its availability as an offline and web-based software. HYSPLIT has already shown good results for the analysis of trajectories during huge anthropogenic (Rolph et al., 2014; Skrynyk et al., 2019) and natural (Lazaridis et al., 2008; Wentworth et al., 2018) pollutant's releases.

During April 2020, severe wildfires occurred in the north of Ukraine after numerous man-made agricultural burning distributed to forestry areas. The Chornobyl Exclusion Zone was among the territories with active fires. The most intense wildfires observed during 4-21 April caused huge pollutants' emission and affected the populated Ukrainian territories, including Kyiv metropolitan area. Despite the negative impact on air quality in April and great concern among people and media, the overwhelming majority of people who use open burning in the agricultural sector does not intend to change their usual practice. Analysis of the consequences after open burning and wildfires might become strong evidence for the agricultural sector and private gardening to change their practices and do not burn plants' remnants. Moreover, results of pollutant distribution during the wildfires will help to develop recommendations about the most appropriate location for background air quality stations and satellite data use for public warning. Considering the mentioned problems, the current study aimed to analyze air quality changes in Ukraine under the wildfires in April 2020. It will help to understand the disadvantages of the monitoring network, develop the methodology of satellite and groundbased data fusion during wildfires, and provide an informational basis for decision-makers.

\section{Data and methods}

Air quality changes over the territory of Ukraine has been analyzed using TROPOMI data from the Sentinel-5P satellite (Internet 1). Among available chemical species derived from Sentinel-5P, the most appropriate for air quality estimation during wildfires are $\mathrm{CO}$ (Borsdorff et al., 2018a; Deeter et al., 2018; Turquety et al., 2007) and $\mathrm{NO}_{2}$ (Mebust et al., 2011; Schreier et al., 2015). CO column number density was selected as the indicator of wildfire emissions and combustion products in the atmosphere. $\mathrm{NO}_{2}$ column number density was used for studying the general state of air quality as the indicator of all-type emissions: wildfire, sta- tionary, and mobile anthropogenic sources. Moreover, $\mathrm{CO}$ and $\mathrm{NO}_{2}$ are the only species that could be compared with ground-based measurements. The national monitoring stations for air quality still do not measure other chemical species that are emitted during wildfires: particulate matter $(\mathrm{PM})$, ozone $\left(\mathrm{O}_{3}\right)$, carbon dioxide $\left(\mathrm{CO}_{2}\right)$, volatile organic compounds (VOC), etc. Absorbing aerosol index (AAI) derived from Sentinel-5P was used for the analysis of the dust storm case during the $16^{\text {th }}$ of April 2020.

Sentinel-5P observed Ukrainian territory between 10 and 11 UTC that corresponds to 1:00 PM and 2:00 
PM of local time. All TROPOMI data were downloaded as Level 2 Products. They were binned by latitude/ longitude using "bin_spatial" procedure (available within "harpconvert" utility) to the grid of $0.05^{\circ} \times 0.05^{\circ}$ of latitude vs. longitude. Data filtering for the removal of statistically unreliable data was made with a quality assurance index exceeding 0.5 .

The directions of $\mathrm{CO}$ and $\mathrm{NO}_{2}$ distribution from the active fires applied using joint analysis with data from Visible Infrared Imaging Radiometer Suite (VIIRS) and Moderate Resolution Imaging Spectroradiometer (MODIS). Geospatial data about large heat releases (from 1 to $200 \mathrm{MWt}$ ) were downloaded from the Fire Information for Resource Management System (Internet 3). Despite fires localizations, there is information for visible spectrum allowing to analyze the direction of smoke distribution. It was used for controlling $\mathrm{CO}$ and $\mathrm{NO}_{2}$ advection. Because of Ukraine's location in moderate latitudes, geographical coordinates were converted from grids to the coordinate system in equidistant conic projection with further polynomial interpolation.

Advection of polluted air masses was analyzed using the web-based HYSPLIT model (Internet 2; Rolph et al, 2017; Stein et al, 2015). It used the ensembles of forward trajectories for wildfires episodes and ensemble of backward trajectories for the dust storm case during the $16^{\text {th }}$ of April 2020. Meteorological input was selected from the archive of Global Forecast System (GFS) data with the spatial resolution $0.25^{\circ}$ of lat- itude vs. longitude. Comparison of HYSPLIT wind and relative humidity output with in-situ measurements implemented using radio-soundings data on the Kyiv station for 00 UTC (16 and 17 April) available at Wyoming University (Internet 4) databases.

Ground-based CO data obtained from the national air pollution measurement network (Central Geophysical Observatory named by Boris Sreznevsky). Overall, 100 stations in 30 cities (Figure 1) were involved in in-situ data analysis and intercomparison with the Sentinel-5P data. The closest stations to wildfires were located $85-100 \mathrm{~km}$ away in Chernigiv and Kyiv. Both cities have numerous local sources of anthropogenic emissions, therefore were highly influenced by them during the wildfire event. All stations in Ukraine are equipped with sensors from national production. There are no measurements of PM, VOC, $\mathrm{BC}, \mathrm{CO}_{2}$ at the Ukrainian national air quality network, hence, the analysis of wildfire pollution could be made using only $\mathrm{NO}_{2}$ and $\mathrm{CO}$ data. Because of the short lifetime of $\mathrm{NO}_{2}$ in the atmosphere and the distance to the closest stations, $\mathrm{CO}$ is the most appropriate pollutant for the study.

Analysis of ground-based data was made considering the national air quality standards: for $\mathrm{CO}$, the daily average threshold value is $3.0 \mathrm{mg} / \mathrm{m}^{3}$, for $\mathrm{NO} 2$ $-0.04 \mathrm{mg} / \mathrm{m}^{3}$. Satellite data cannot be recalculated to ground-based values. However, some approximations could be done for the analysis of pollutants' content over wildfires. Let us suppose the pollutant distributes

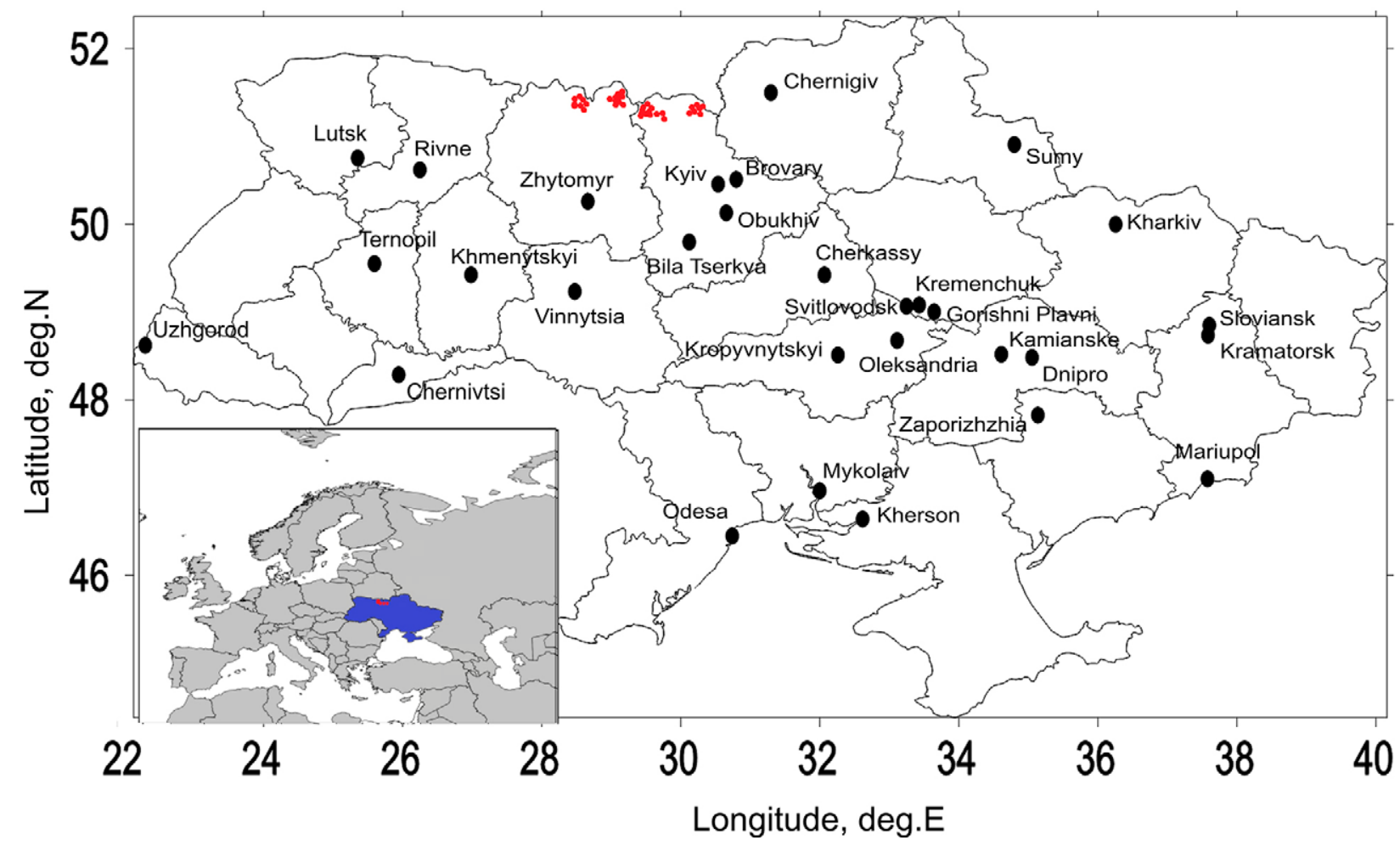

Figure 1. Cities with ground-based measurements (black dots) and locations of main wildfires that affected air quality the most (red dots) 
in the lower 200 meters layer $(H)$ over wildfire and its concentrations $(C)$ are equally distributed through the layer $H$. Therefore, the approximate near-ground value in $[\mathrm{mg} / \mathrm{m} 3]$ is:

$$
C=\frac{C_{c o l}}{H} \cdot M \cdot A
$$

where $C_{c o l}$ - pollutant column content $\left[\mathrm{mol} / \mathrm{m}^{2}\right], M$ - molar mass [g/mol], $A$ - constant that equals 1000 for conversion from $\left[\mathrm{g} / \mathrm{m}^{3}\right]$ to $\left[\mathrm{mg} / \mathrm{m}^{3}\right]$. $\mathrm{H}$ is expressed in $[\mathrm{m}]$. According to our assumptions, near-ground values could reach dangerous for human health air quality levels (according to the national threshold standard) if column number density reaches 200 $\mathrm{mmol} / \mathrm{m}^{2}$ for $\mathrm{CO}$ and $130 \mu \mathrm{mol} / \mathrm{m}^{2}$ for $\mathrm{NO}_{2}$.

\section{Results}

Wildfire episodes and air quality changes

The wildfire event in April 2020 in the northern part of Ukraine could be divided into two main episodes: 4-14 April and 15-21 April. During the first episode, wildfire emissions spread from two large burning areas of the north of the Kyiv oblast (region). One burning area located near Krasiatychi on the north-west, another one - in the Chornobyl Exclusion Zone. The second period corresponded to the wildfires in the north of the Zhytomyr oblast (region) with the most severe fires near the border of the Kyiv oblast.

Background values of $\mathrm{CO}$ column number density were $30 \mathrm{mmol} / \mathrm{m}^{2}$ that accidentally increased to 40 $50 \mathrm{mmol} / \mathrm{m}^{2}$ after the largest wildfire emissions. Local CO maximums which were observed in the first days of April did not correspond to the wildfires and appeared over the territories with intense agricultural burning. Emission of burning products from the fields caused CO content, increasing up to 70 $90 \mathrm{mmol} / \mathrm{m}^{2}$. During 1-4 April, CO column number density over agricultural lands was 1.5 times higher than over wildfires and 2-2.5 times higher than background values. Nevertheless, recalculation to groundbased values did not show dangerous levels of $\mathrm{CO}$ for human health. $\mathrm{NO}_{2}$ column number density varied within $30-70 \mu \mathrm{mol} / \mathrm{m}^{2}$ with higher content over big cities and industrial zones, reaching $120 \mu \mathrm{mol} / \mathrm{m}^{2}$ that approximately was close to threshold limits after approximate recalculation to ground-based values. $\mathrm{NO}^{2}$ maximums with the values of $350-1500 \mu \mathrm{mol} / \mathrm{m}^{2} \mathrm{ob}-$ served over wildfires, however, at the distances of about $30-50 \mathrm{~km}$ away from burning areas, $\mathrm{NO}^{2}$ column number density was close to the levels over industrial regions (Figure 2). These concentrations were 3-10 times higher than threshold values.

Severe wildfires and huge pollutants' emission occurred on the $6^{\text {th }}$ of April. It caused CO column number density to increase to $100-190 \mathrm{mmol} / \mathrm{m}^{2}$ (Figure 3) and exceed $250 \mathrm{mmol} / \mathrm{m}^{2}$ during 12-13 April. These $\mathrm{CO}$ values have exceeded $200 \mathrm{mmol} / \mathrm{m}^{2}$ which we assume equals the national standard threshold value for CO. Before the $7^{\text {th }}$ of April, deterioration of air quality observed near the territories of active fires in the Chornobyl Exclusion Zone. Further emissions caused CO spreading far from the burning areas, influencing air quality in highly populated regions. $\mathrm{NO}_{2}$ emissions during 6-14 April affected insignificantly cities located at distances more than $50 \mathrm{~km}$ away from the wildfires. Moreover, during one of the biggest wildfire emissions on the $12^{\text {th }}$ of April, there were detected extremely high $\mathrm{NO}_{2}$ maximum over Kyiv (of about $200 \mu \mathrm{mol} / \mathrm{m}^{2}$ ) of local anthropogenic origin. That day, the $\mathrm{NO}_{2}$ column number density was 3 times higher than over adjacent territories. It had happened af-

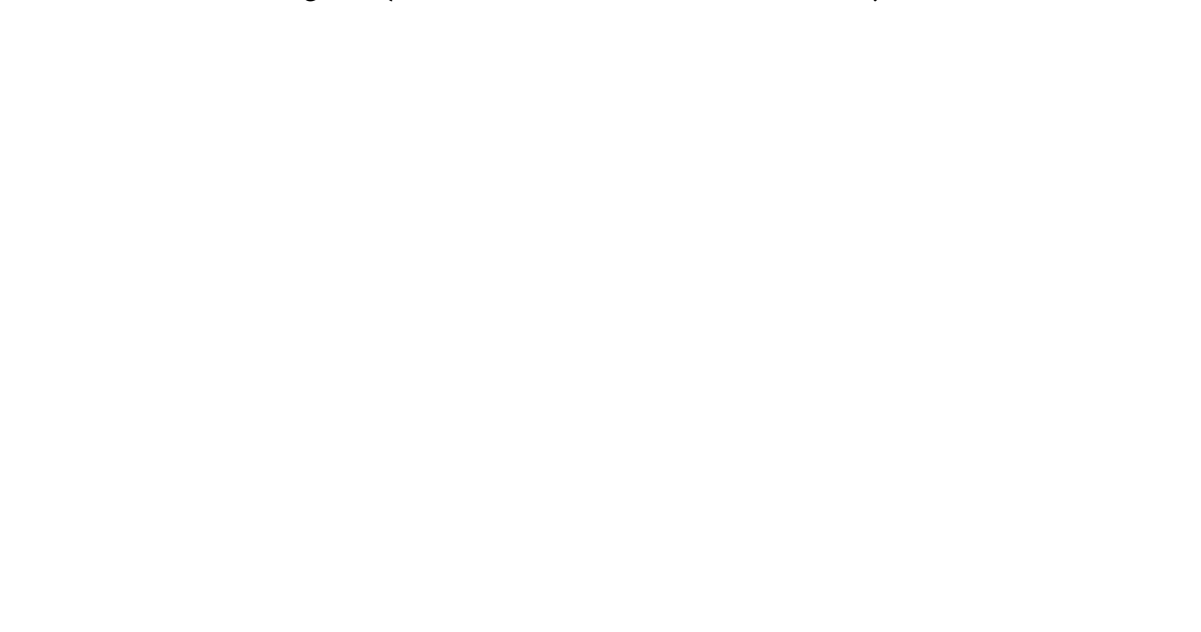

Figure 2. Spatial distribution of $\mathrm{NO}_{2}$ column number density on 18 April 2020 


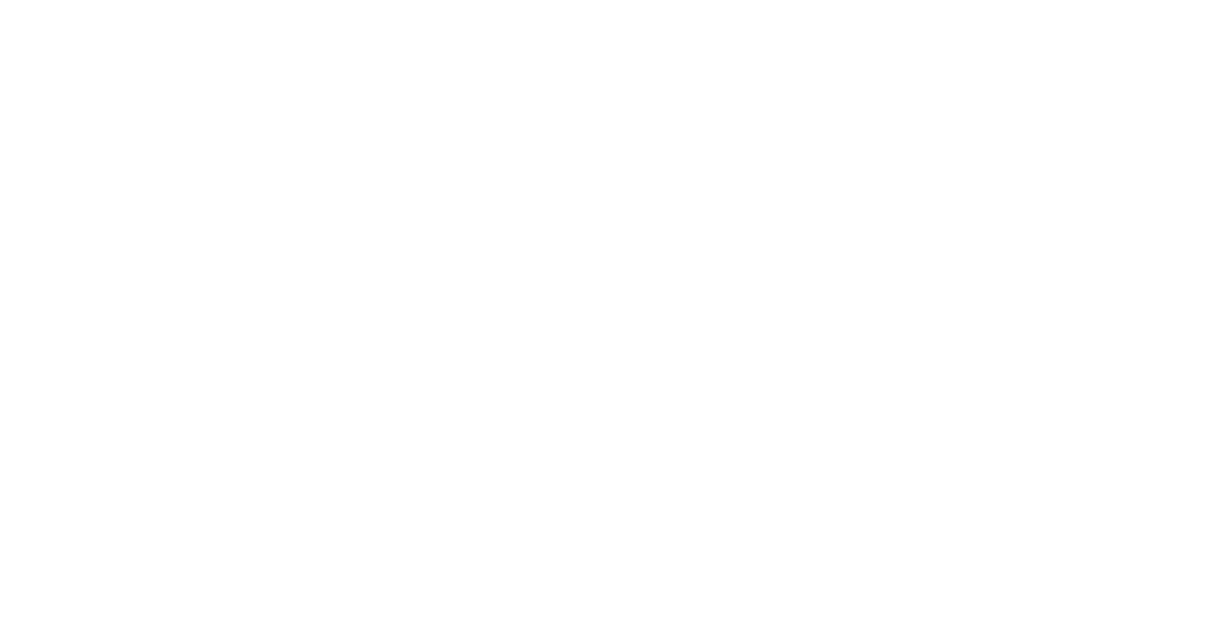

Figure 3. Spatial distribution of CO column number density on 10 April 2020

ter a previous 2-day wind blowing from the Chornobyl Exclusion Zone towards Kyiv as seen from Figure 3. Even though the wind had already changed direction and air quality had deteriorated after local emissions, it caused a great concern of local citizens, who did not believe authorities about real air quality levels and blamed for ineffective actions towards extinguishing wildfires.

Using the HYSPLIT model, the trajectories of burning products spreading were calculated (Appendix A). Joint analysis with TROPOMI data allowed finding territories affected by elevated pollution levels. Trajectories were calculated from the largest active fires starting from 00 UTC. Each point on trajectories shown on the maps in Appendix A represents the air mass location lhour after the previous one.

During the first episode from the $4^{\text {th }}$ to $14^{\text {th }}$ of April 2020, only 4 days were characterized by wildfire emissions spreading out from the Chornobyl Exclusion Zone (Appendix A). During the $8^{\text {th }}$ of April, west wind caused a burning products distribution towards the north-eastern part of Ukraine. The Bela- rusian territories were affected by elevated pollution levels on the $9^{\text {th }}$ of April and the whole Kyiv oblast (region) during 10-11 April. These events resulted in 1.52 times $\mathrm{CO}$ increase over background values reaching $80 \mathrm{mmol} / \mathrm{m}^{2}$. During the $12^{\text {th }}$ of April, wildfire emissions from the areas near Krasiatychi distributed to Belarus, whereas burning products from fires in the Chornobyl Exclusion Zone - to the north-eastern part of Ukraine.

The first episode of the wildfire event ended on the $14^{\text {th }}$ of April after precipitation that helped firefighters to extinguish the open fires. During the second episode of the wildfires with the largest ones in the north of the Zhytomyr oblast (region), huge emissions occurred after strong west wind on the territory of Ukraine. Maximum values of CO column number density reached $190 \mathrm{mmol} / \mathrm{m}^{2}$. During 16-19 April, polluted air masses spread to the east through the south-east with $\mathrm{CO}$ content of $80-110 \mathrm{mmol} / \mathrm{m}^{2}$ at the distances of about $260-300 \mathrm{~km}$ from active fires (Figure 4). $\mathrm{NO}_{2}$ column number density was high near active fires reaching $1300 \mu \mathrm{mol} / \mathrm{m}^{2}$ which was about 10

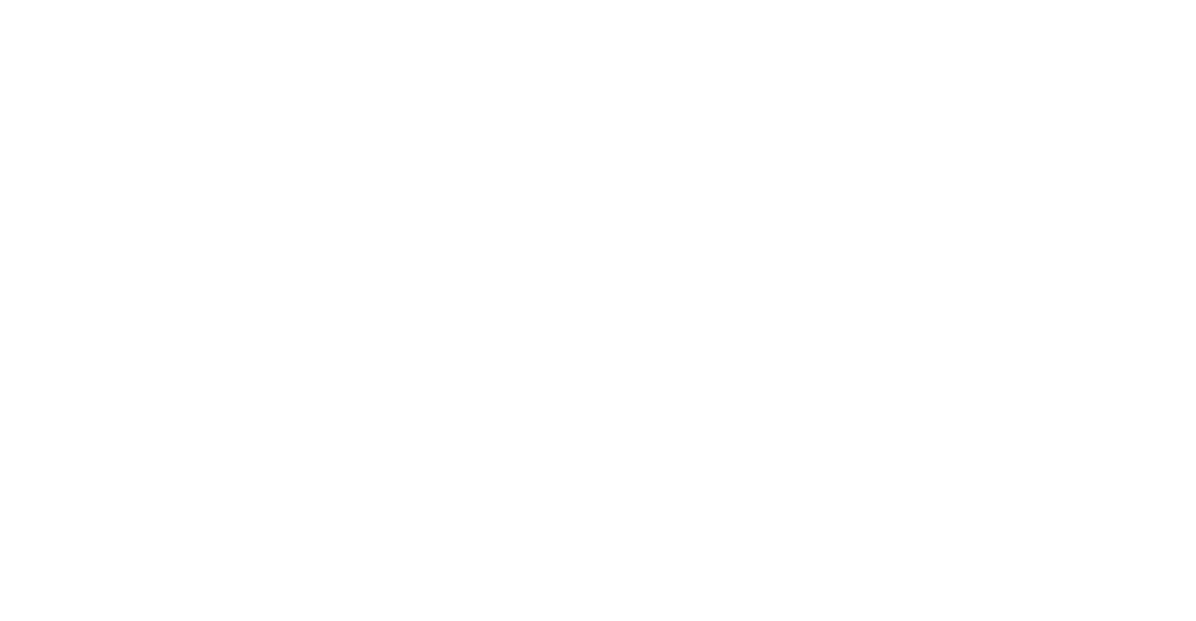

Figure 4. Spatial distribution of CO column number density on 17 April 2020 
times higher than approximate recalculation to nearground threshold values. Local maximums also were observed over big cities and industrial regions with values of about $200 \mu \mathrm{mol} / \mathrm{m}^{2}$.

The maps from Appendix B clearly show that burning products have spread at large distances due to strong winds. On the $16^{\text {th }}$ of April, it took about 6 hours for air masses to pass $400 \mathrm{~km}$. Wind speed gradually decreased during 17-19 April, and these days it took 12 hours for burning products to spread over $450 \mathrm{~km}, 350 \mathrm{~km}$, and $250 \mathrm{~km}$, respectively.

Most wildfires were extinguishing after the $20^{\text {th }}$ of April, and $\mathrm{CO}$ content rapidly decreased to values lower than $70 \mathrm{mmol} / \mathrm{m}^{2}$. The background $\mathrm{CO}$ values were between 40 and $50 \mathrm{mmol} / \mathrm{m}^{2}$.

\section{In-situ carbon monoxide variability}

Ground-based CO data weren't as sensitive to the wildfire emissions as $\mathrm{CO}$ total column changes derived from Sentinel-5P. Despite air quality was getting worse, and the stable smell of burning products was in the atmosphere, monitoring stations in most cities showed only a slight $\mathrm{CO}$ increase during the periods of active spreading toward cities (Figure 5). The overwhelming majority of stations are located close to huge anthropogenic sources, and there are no background stations in Ukraine. Thus, CO variability mainly showed usual behavior that is typical for anthropogenically loaded places. As was mentioned above, $\mathrm{NO}_{2}$ concentrations significantly increased over the regions with active fires. Therefore, analysis of $\mathrm{NO}_{2}$ changes in cities does not make sense because the concentrations' maximums represent only local anthropogenic emissions. Some impacts might have the altitudes of pollutants' distribution. Usually, vertical motion was observed, and concentrations ascended above the heights where ground-based sensors were located. However, the stations' location from the available ground-based network was unable to properly indicate air quality worsening in cities during the wildfire event.

There are three regions in Ukraine where the fingerprint of the wildfire emissions could be seen at the lowest atmospheric layer in cities. The closest territories in the northern part of Ukraine (represented by Kyiv in Figure 5), the central part (e.g. Zaporizhzhia), and the eastern - north-eastern regions (e.g. Kharkiv). The orange-colored background on the plots from Figure 5 corresponds to $\mathrm{CO}$ values that exceed the threshold according to the national standard $(3 \mathrm{mg} /$ $\mathrm{m}^{3}$ for average values).

Cities in the north of Ukraine were affected mostly by the burning products spread during 10-11 April and 17-19 April. CO concentrations during these episodes were approximately $10-20 \%$ higher. However,

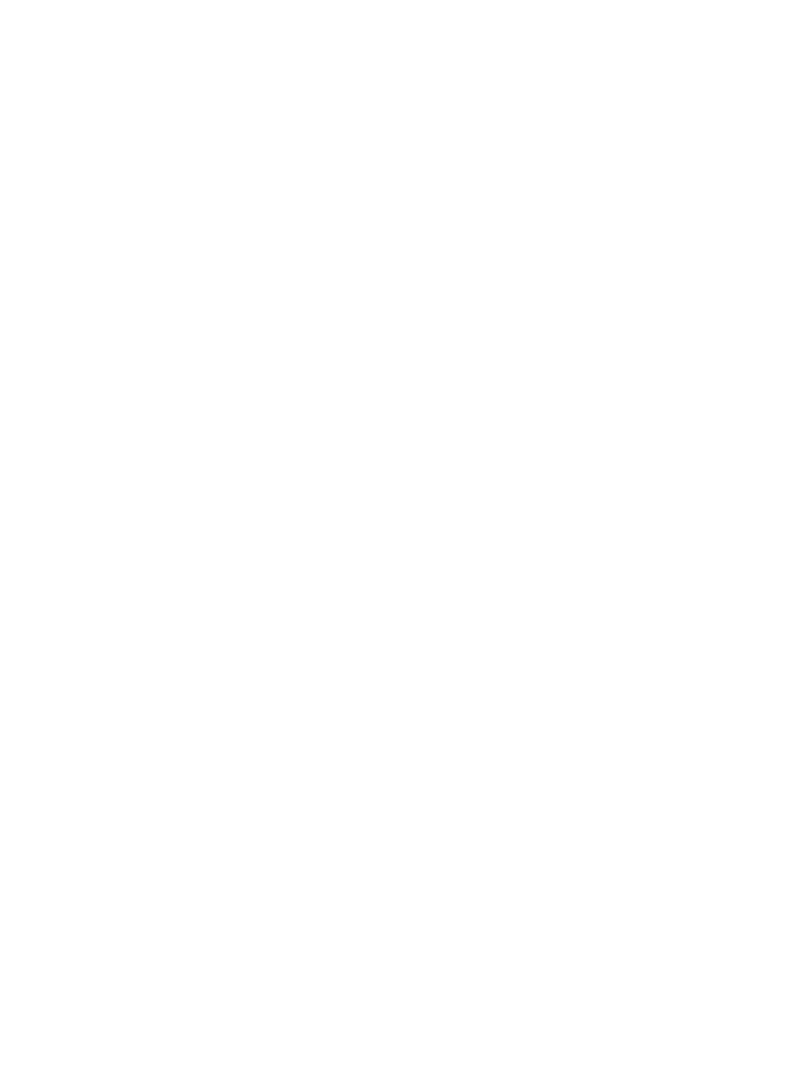

Figure 5. Temporal variability of ground-based CO $\left(\mathrm{mg} / \mathrm{m}^{3}\right)$ measurements. Red columns represent measurements during the periods of burning products spreading over cities. Orange background indicates threshold $\mathrm{CO}$ values according to the national regulations

maximums observed after local anthropogenic emissions within cities (e.g. the $8^{\text {th }}$ and $15^{\text {th }}$ of April as seen in Kyiv) and after open burning episodes during the first days of April (e.g. 4-6 April).

Cities in the north-eastern and eastern parts of Ukraine were affected mostly on the $8^{\text {th }}$ of April and during 16-17 April (see Kharkiv in Figure 5). In both cases, maximum values were detected 12-24 hours after polluted air masses reached the territories. The possible explanation could be $\mathrm{CO}$ descent to the surface layer after it spread to the region at higher altitudes. However, the differences between observed values were less than $10 \%$.

The central part of Ukraine was the only region where ground-based stations detected wildfires emissions in cities rather well (see Zaporizhzhia in Figure 5). During the second episode of the wildfire, polluted air masses appeared during 17-19 April and resulted in the in-situ CO concentrations leaping to $200-250 \%$ in comparison to average content.

The April 2020 wildfire event showed the main problem of the available ground-based network that did not indicate background, especially during pollutants' emission in remote regions. Appropriate analysis of health risks cannot be done only by using in-situ 
data. Usage of satellite data must give necessary information for decision-making in Ukraine during the possible future wildfire events and their negative impact on air quality.

Relation between satellite and ground-based data Intercomparison of satellite and ground-based $\mathrm{CO}$ data is a complex task for the Ukrainian network. The main problem is a 6-hour difference between Sentinel-5P sensing (approximately 1:00-2:00 PM of local summertime) and $\mathrm{CO}$ in-situ measurements (7:00 AM and 7:00 PM). Hence, no direct intercomparison is possible. Historically, the network was established near powerful emission sources in cities: thermal power plants, factories, busy roads, etc. As a result, $\mathrm{CO}$ measurements largely showed huge anthropogenic emissions and there are only a few stations that could be considered as urban background. This fact negatively impacts the signal/noise ratio during the analysis of the wildfires' fingerprint in the $\mathrm{CO}$ time series. Moreover, approximately half of the stations measure $\mathrm{CO}$ with an accuracy of $0.1 \mathrm{mg} / \mathrm{m}^{3}$, while others $-1 \mathrm{mg} / \mathrm{m}^{3}$. Therefore, many values are too rough for precise analysis.

All mentioned problems influenced $\mathrm{CO}$ data intercomparison; and, as expected, the correlation between satellite and ground-based data was insignificant (lower than $r=0.15)$. However, $\mathrm{CO}$ at some stations rather well coincided with TROPOMI data. First of all, the 7:00 AM data were better comparable than the 7:00 PM ones, reaching a statistically significant correlation on 36 out of 96 stations located in 25 cities. The highest values $(r=0.70-0.82)$ were in Gorishni Plavni and Zaporizhzhia (the central part of Ukraine), where a large number of stationary $\mathrm{CO}$ emission sources are located. In both cities, the maximum values were detected during 17-18 April, when wildfire emissions spread from the northern part of Ukraine. During this episode, CO column number density reached $60 \mathrm{mmol} / \mathrm{m}^{2}$ and $40 \mathrm{mmol} / \mathrm{m}^{2}$ over Gorishni Plavni and Zaporizhzhia, respectively. CO near-ground con- centrations were 3-5 times higher than average values: $1 \mathrm{mg} / \mathrm{m}^{3}$ and $3 \mathrm{mg} / \mathrm{m}^{3}$, respectively.

High correlation up to $r=0.70$ was also on the stations in the western part of Ukraine, e.g., in Ternopil, Khmelnytskyi, etc. These cities weren't affected by wildfire emissions. In general, TROPOMI data better represented pollution over the cities, which were episodically affected by short-term wildfire emissions spreading. The closer the city to active fires and the more frequent $\mathrm{CO}$ advection observed, the worse correlation with satellite data was. Nevertheless, the episodes of the most severe elevated pollution levels at the surface layer coincide with satellite data.

Despite rather low coincidence between single CO values, the analysis of grouped data showed significant linear dependence (Figure 6).

If in-situ $\mathrm{CO}$ values are within $0-1 \mathrm{mg} / \mathrm{m}^{3}$ interval, the average CO column number density does not exceed $40 \mathrm{mmol} / \mathrm{m}^{2}$. According to the found relation, every $2 \mathrm{mg} / \mathrm{m} 3$ in the surface layer represented the average CO column number density increase by $1 \mathrm{mmol} /$ $\mathrm{m}^{2}$. On the one hand, Figure 6 represents a clear relation between satellite and ground-based data. On the other hand, changes in average values corresponding to particular gradation are too low. As a result, it is difficult to create a reliable analytical solution for the combination of Sentinel-5P and in-situ CO measurements from the Ukrainian network. Results of intercomparison might be used for future ground-based network optimization.

\section{Dust storm during 16 April \\ and corresponding changes}

On the $16^{\text {th }}$ of April, strong winds formed the dust storm which passed the northern part of Ukraine. Despite the end of the first wildfire episode, air quality in Ukraine was significantly affected by aerosol spreading. Dust storm occurred in the daytime and preceded the second wildfire episode that started later in the evening. Sentinel-5P sensing at 1000-1030 UTC caught the dust storm at the moment it passed Zhy-
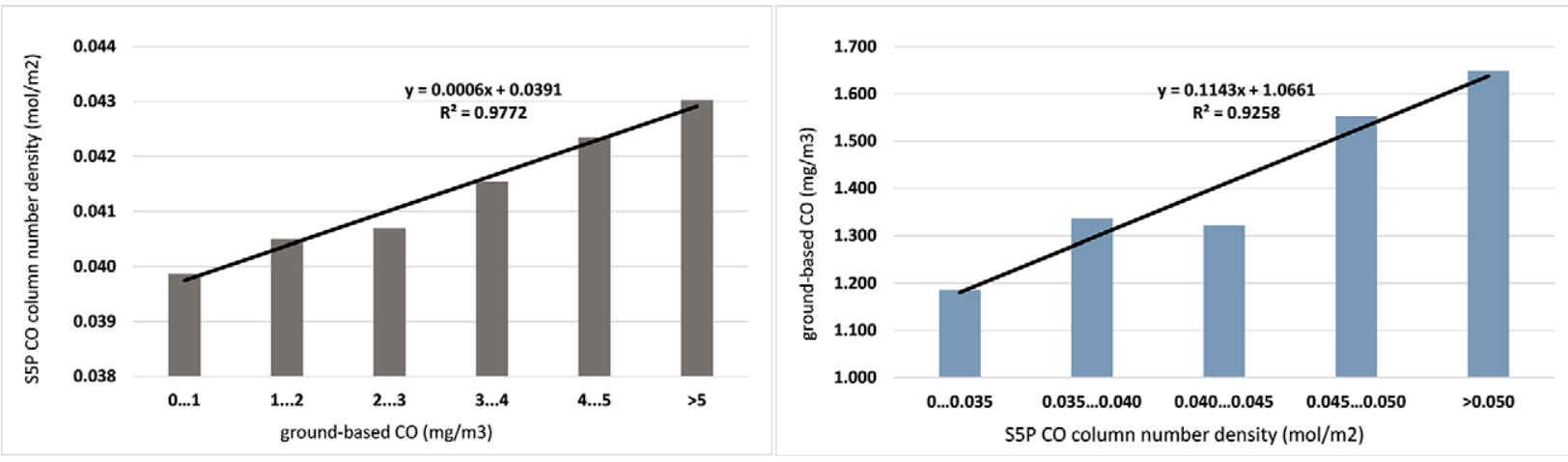

Figure 6. Dependencies between ground-based $\mathrm{CO}\left(\mathrm{mg} / \mathrm{m}^{3}\right)$ measurements and TROPOMI CO column number density $\left(\mathrm{mol} / \mathrm{m}^{2}\right)$ data 


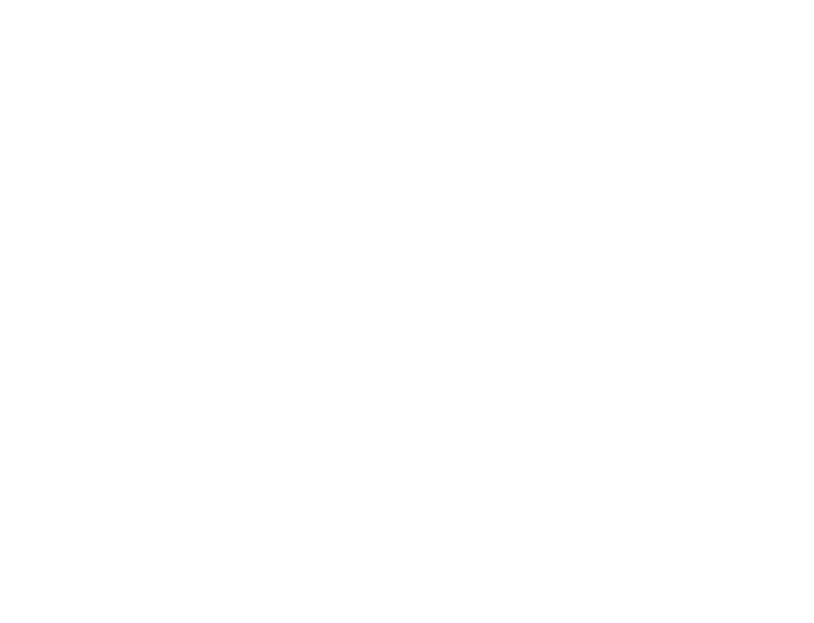

Figure 7. Spatial distribution of AAI during the dust storm on 16 April 2020

tomyr and before reaching Kyiv as shown in Figure 7. AAI over the area affected by the dust storm reached $0.8-1$, while adjacent territories were characterized by negative values.

Based on HYSPLIT backward trajectories (Figure 8), there were analyzed the territories in which air mass passed before the moment of Sentinel-5P sensing. During the dust storm, there was a persistent smell of burning products in the atmosphere, but the air masses did not pass any territories with active fires. From March through the beginning of April, agricultural open burning was widespread on the terri-

Backward trajectories ending at 1000 UTC 16 Apr 20 GFSQ Meteorological Data

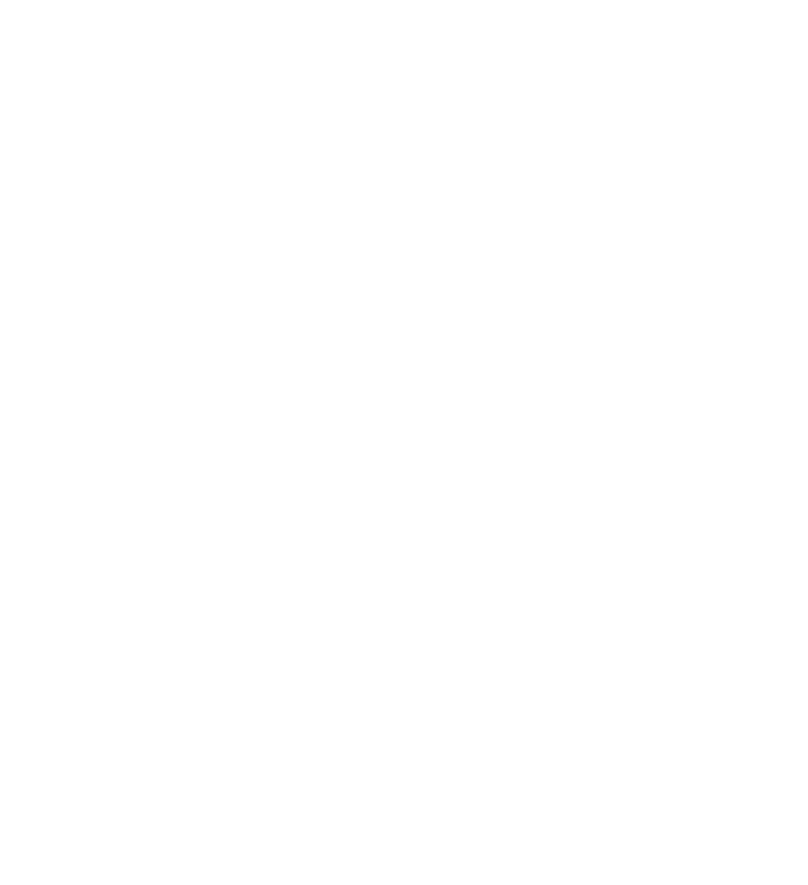

Figure 8. Ensemble of backward trajectories based on the HYSPLIT model and relative humidity distribution on the way of the dust storm tories the air masses passed. Considering these facts, the burning products probably were raised from the ground and were not connected with the wildfire event described in this study.

Air masses, which caused the dust storm, penetrated the Ukrainian territory approximately at 0304 UTC and it takes about 6-7 hours to pass $400 \mathrm{~km}$ before the Sentinel-5P measured elevated aerosol content (approximately at 1000-1030 UTC). Based on the HYSPLIT model results, the wind speed was about 15 $\mathrm{m} / \mathrm{s}$ at the height of $500 \mathrm{~m}$ above the surface. If we take a look at radio-soundings data available for 00 UTC on the $16^{\text {th }}$ and $17^{\text {th }}$ of April (Figure 9), we could see similar values. At the near-surface layer, the wind speed was about $4 \mathrm{~m} / \mathrm{s}$, gradually increasing up to 12 $\mathrm{m} / \mathrm{s}$ at $500 \mathrm{~m}$ above the surface. At the height of more than $1200 \mathrm{~m}$, there were observed significant differ-

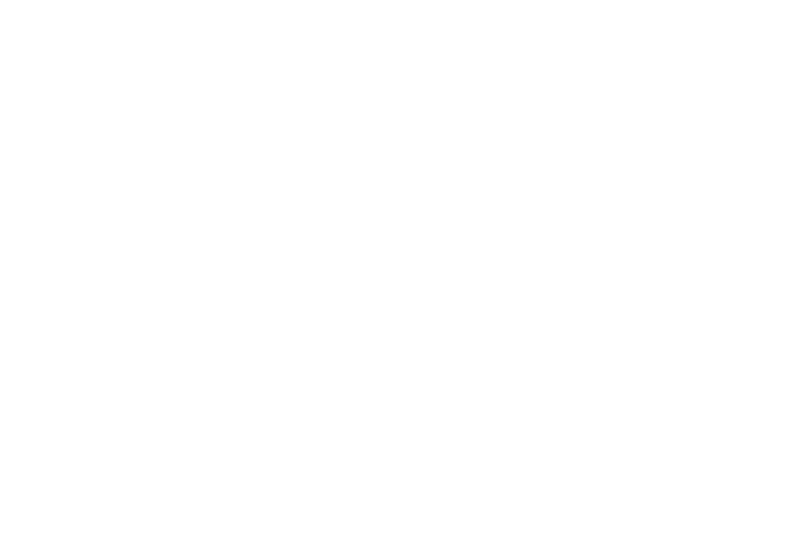

Figure 9. Vertical distribution of wind speed and relative humidity on the Kyiv station before and after the dust storm

ences in wind speed before and after the dust storm. The wind speed difference between two neighbor observations reached $8 \mathrm{~m} / \mathrm{s}$ at $2000 \mathrm{~m}$ above the surface (an increase from 16 to $24 \mathrm{~m} / \mathrm{s}$ ). Taking into account the values and constantly increasing strong wind during the $16^{\text {th }}$ of April, the reasons for dust storm formation under the long period of dry atmospheric conditions in Ukraine become clear.

Relative humidity on the way of the air masses which caused the dust storm varied from $58 \%$ to $80 \%$ (Figure 8 ). However, the difference in water vapor content is well seen on radio-soundings data. At 00 UTC on the 16th of April, before the dust storm occurred, relative humidity was about $65-80 \%$ at the lowest $2000 \mathrm{~m}$ layer. After the advection of new air masses, relative humidity decreased by $20-40 \%$ depending on the height. At 00 UTC on the $17^{\text {th }}$ of April, the highest ever observed value in the vertical profile of relative humidity was 58\% (approximately $600 \mathrm{~m}$ above the surface). Such unfavorable conditions were also one of the causes of the dust storm. 
The study showed an accurate scenario of atmospheric air pollution as a result of the wildfire event. Data derived from Sentinel-5P had been used for decisionmaking of the State Emergency Service of Ukraine in April 2020. The study also gives the evidence of possibility for wildfire emissions tracking using satellite measurements that have been previously mentioned in different studies (Abida et al., 2017; Edwards et al., 2006; Sundström et al., 2020). Nevertheless, some disadvantages appear when hourly data is needed. In this case, satellites cannot satisfy and provide a continuous picture of pollutants changes. Atmospheric and chemistry modeling significantly improves results (Konovalov et al., 2011). Hence, it is better to use modeling for different vertical levels in the future.

After a comparison with ground-based data from the national air quality monitoring network, some uncertainties were found. These uncertainties have appeared because of a bit outdated stations which are located close to the main anthropogenic sources (there are no background stations). Overall, TROPOMI data achieves better accuracy in comparison to previous satellite missions (Cooper et al., 2020; Yurganov et al., 2011). All these results prove the opportunity to use Sentinel-5P for air quality monitoring, including wildfire events. $\mathrm{NO} 2$ total column data were found to be biased between 20-30\% (Verhoelst et al., 2020). CO field comparison with the ECMWF assimilation system showed a $3.2 \pm 5.5 \%$ mean difference (Borsdorff et al., 2018b). TROPOMI total columns underestimate ground-based observations but slightly overestimate small total column values (Ialongo et al., 2020). We found dependencies for CO column number density only between certain groups of values.

A comparison of satellite and ground-based data in our study showed better coincidence for CO column number density. It happened due to a longer CO lifetime in the atmosphere, therefore, it was detected far away from the active fires. Usually, CO exists for more than 10 days in the atmosphere (Adams et al., 2019;
Whitburn et al., 2015). Approximate recalculation of Sentinel-5P data to near-ground values was well-compatible with a wildfire episode in 2010 (Konovalov et al., 2011). We calculated that $\mathrm{CO}$ was higher than 5 $\mathrm{mg} / \mathrm{m}^{3}$, whereas over the Moscow region in 2010, it increased up to $10 \mathrm{mg} / \mathrm{m}^{3}$ (Konovalov et al., 2011).

The wildfire event in April 2020 has revealed a number of problems of the national monitoring network that significantly complicates adequate society warning. Firstly, the location of stations in cities near sources of strong anthropogenic emissions makes it difficult to define real consequences for air quality. Secondly, CO is measured only at 7:00 AM and 7:00 PM (local time), which makes a direct comparison with Sentinel-5P data available approximately at 1:00 PM (local time) impossible. Thirdly, a poor set of species that are measured at monitoring sites provides only $\mathrm{CO}$ and $\mathrm{NO}_{2}$ data for wildfire emissions monitoring. The solution divides into two directions: the establishment of background stations and improvement of sensors which must measure at least PM and $\mathrm{O}_{3}$ providing air quality data more frequently than 2-4 times per day.

Forward and backward trajectories derived from the HYSPLIT model partially fill the gap in observations and allow defining the areas affected by pollution distribution. Recently, HYSPLIT has already been used for the analysis of wildfires (Chai et al., 2020; Kim et al., 2020; Li et al., 2020) and dust storm episodes (Kalkstein et al., 2020).

AAI is commonly used to identify dust storms, including its early warning (UNEP, 2013) and identification of the sources (Broomandi et al., 2017). The current study also contains results of AAI satellite data usage for the operational purpose in Ukraine. On the $16^{\text {th }}$ of April 2020, the dust storm was caught by Sentinel-5P over Ukraine. It had happened a few hours before the dust covered Kyiv, the capital of Ukraine. Using satellite near real-time data, the State Emergency Service of Ukraine was informed about the oncoming dust storm.

\section{Conclusions}

During the April 2020 wildfire event, different Ukrainian territories were affected several times by elevated pollution levels. The wildfire occurred in the north of Ukraine and consisted of two main episodes: 4-14 April and 16-21 April. CO column number density reached $250 \mathrm{mmol} / \mathrm{m}^{2}$ near active fires during the first episode; however, $50 \mathrm{~km}$ away from the fires, $\mathrm{CO}$ content was 2-3 times lower. $\mathrm{NO}_{2}$ col- umn number density reached $1300 \mu \mathrm{mol} / \mathrm{m}^{2}$, and concentrations sufficiently decreased at the same distance being close to typical values over urban areas. During the second episode, wildfire emissions were lower, however, polluted air masses spread for more than $300 \mathrm{~km}$ away from active fires due to unfavorable weather conditions with strong unidirectional wind. 
Ground-based air pollution measurements insufficiently indicated wildfire episodes, despite the persistent smell of burning products in the air. It is connected with the stations' locations close to huge anthropogenic sources that weren't so sensitive to remote wildfire emissions. There were identified regions where in-situ measurements identified the fingerprint of wildfires: the northern, north-eastern, and central parts of Ukraine.

Intercomparison of TROPOMI CO column number density and ground-based concentrations mainly showed bad results due to a 6-hour difference between Sentinel-5P sensing (10:00 AM UTC) and in-situ measurements. Thus, a statistically significant correlation with 04 UTC ground-based data was found. The highest correlation up to $r=0.70$ was found with stations that weren't affected by wildfire emissions. In general, the closer the city is located to active fires and the more often polluted air masses are emitted, the worse correlation is found.

During the $16^{\text {th }}$ of April, the dust storm affected air quality in the north of Ukraine. It was visible by Sentinel-5P via AAI distribution. The main reasons for this dust storm formation were high wind speed and low humidity with the values of $50-60 \%$ in the surface layer.

\section{Acknowledgments}

The study is based on the results from operational monitoring and research of the April 2020 wildfire event made by the authors for decision-making of the State Emergency Service of Ukraine. We acknowledge everyone who is involved in the functioning of the Copernicus Open Access Hub, providing near real-time Sentinel-5P data that has become vital for extinguishing wildfires.

We are grateful for organizers and tutors of the Remote Sensing course by the Trans-Atlantic Training
(TAT-7) "Radar and Optical Remote Sensing in the Agriculture and Environmental Monitoring" (Novi Sad, Serbia, 20-24.06.2019) and the First Joint Training Course on Atmospheric Composition (Cluj-Napoka, Romania, 04-08.11.2019) for financial support, training and skills development of our scientists involved in operational monitoring and current research.

We acknowledge reviewers for valuable comments and suggestions that improve the quality of the presented paper.

\section{References}

Abida, R., Attié, J.-L., El Amraoui, L., Ricaud, P., Lahoz, W., Eskes, H., Segers, A., Curier, L., de Haan, Kujanpää, J., Nijhuis, A.O., Tamminen, J., Timmermans, R., \& Veefkind, P. (2017). Impact of spaceborne carbon monoxide observations from the S-5P platform on tropospheric composition analyses and forecasts. Atmospheric Chemistry Physics, 17, 1081-1103

Adams, C., McLinden, C.A., Shepard, M.W., Dickson, N., Dammers, E., Chen, J., Makar P., Cady-Pereira, K.E., Tam, N., Kharol, S.K., Lamsal, L.N., \& Krotkov, N.A. (2019) Satellite-derived emissions of carbon monoxide, ammonia, and nitrogen dioxide from the 2016 Horse River wildfire in the Fort McMurray area. Atmospheric Chemistry and Physics, 19, 2577-2599

Balabukh, V., \& Malytska, L. (2017). Impact of climate change on natural fire danger in Ukraine. Idojaras, 4(121), 453-477

Borsdorff, T., Andrasec, J., van de Brugh, J., Hu, H., Aben I. \& Landgraf, J. (2018a). Detection of carbon monoxide pollution from cities and wildfires on regional and urban scales: the benefit of CO column retrievals from SCIAMACHY $2.3 \mu \mathrm{m}$ measurements under cloudy conditions. Atmospheric Measurement Techniques, 11, 2553-2565.
Borsdorff, T., Aan de Brugh, J., Hu, H., Aben, I., Hasekamp, O., \& Landgraf, J.(2018b). Measuring carbon monoxide with TROPOMI: First results and a comparison with ECMWF-IFS analysis data. Geophysical Research Letters, 45, 2826-2832

Brennan, J., Gómez-Dans, J.L., Disney, M., \& Lewis, P. (2019) Theoretical uncertainties for global satellite-derived burned area estimates. Biogeosciences, $16,3147-3164$.

Broomandi, P., Dabir, B., Bonakdarpour, B. \& Rashidi, Y. (2017). Identification of the sources of dust storms in the City of Ahvaz by HYSPLIT. Pollution, 3(2), 341-348.

Chai, T., Kim, H., Stein, A., Tong, D., Li, Y., \& Kondragunta, S. (2020). A case study of the 2018 Camp Fire event using HYSPLIT-based emission inverse modeling system with GOES Advanced Baseline Imager (ABI) observations and other measurements for wildfire smoke forecasts. EGU General Assembly, EGU2020-12525

Coen, J.L., Cameron, M., Michalakes, J., Patton, E.G., Riggan, P.J. \& Yedinak, K.M. (2013). WRF-Fire: Coupled Weather-Wildland Fire Modeling with the Weather Research and Forecasting Model. Journal of Applied Meteorology and Climatology, 52 (1), 16-38. 
Cooper, M.J., Martin, R.V., McLinden, C.A., \& Brook, J.R. (2020). Inferring ground-level nitrogen dioxide concentrations at fine spatial resolution applied to the TROPOMI satellite instrument. Environmental Research Letters, 15, 104013

Deeter, M.N., Martínez-Alonso, S., Andreae, M.O. \& Schlager, H. (2018). Satellite-Based Analysis of CO Seasonal and Interannual Variability Over the Amazon Basin. Journal of Geophysical Research: Atmospheres, 123, 5641-5656.

Doerr, S. H., \& Santín, C. (2016). Global trends in wildfire and its impacts: perceptions vs. realities in a changing world. Philosophical Transactions of the Royal Society B Biological Sciences, 371, 20150345

Duncan, B.N., Prados, A.I., Lamsal, L.M., Liu, Y., Streets, D.G., Gupta, P., Hilsenrath, E., Kahn, R.A., Nielsen, J.E., Beyersdorf, A.J., Burton, S.P., Fiore, A.M., Fishman, J., Henze, D.K., Hostetler, C.A., Krotkov, N.A., Lee, P., Lin, M., Pawson, S., Pfister, G., Pickering, K.E., Pierce, R.B., Yoshida, Y., \& Ziembah, L.D. (2014). Satellite data of atmospheric pollution for U.S. air quality applications: Examples of applications, summary of data end-user resources, answers to FAQs, and common mistakes to avoid. Atmospheric Environment, 94, 647-662

Eastham, S. D. \& Jacob, D. J. (2017). Limits on the ability of global Eulerian models to resolve intercontinental transport of chemical plumes. Atmospheric Chemistry and Physics, 17, 2543-2553.

Edwards, D.P., Emmons, L.K.,Gille, J.C., Chu, A., Attie J.-L., Giglio, L., Wood, S.W., Haywood, J., Deeter, M.N., Massie, S.T., Ziskin D.C., \& Drummond, J.R. (2006). Satellite-observed pollution from Southern Hemisphere biomass burning. Journal of Geophysical Research, 111, D14312

Engel-Cox, J.A., Hoff, R.M., \& Haymet, A.D.J. (2004). Recommendations on the Use of Satellite RemoteSensing Data for Urban Air Quality. Journal of the Air \& Waste Management Association, 54:11, 1360 1371

Galytska, E., Danylevsky, V., Hommel, R., \& Burrows, J.P. (2018). Increased Aerosol Content in the Atmosphere over Ukraine During Summer 2010. Atmospheric Measurement Techniques, 11, 2101-2118.

Griffin, D., Sioris, C., Chen, J., Dickson, N., Kovachik, A., de Graaf, M., Nanda, S., Veefkind, P., Dammers, E., McLinden, C.A., Makar, P., \& Akingunola, A. (2020). The 2018 fire season in North America as seen by TROPOMI: aerosol layer height intercomparisons and evaluation of model-derived plume heights. Atmospheric Measurement Techniques, 13, 1427-1445.

Heilman, W. E., Liu, Y., Urbanski, S., Kovalev, V., \& Mickler, R. (2014). Wildland fire emissions, carbon, and climate: Plume rise, atmospheric transport, and chemistry processes. Forest Ecology and Management, 317, 70-79

Ialongo, I., Virtal, H., Eskes, H., Hovila, J. \& Douros, J. (2020). Comparison of TROPOMI/Sentinel-5 Precursor NO2 observations with ground-based measurements in Helsinki. Atmospheric Measurement Techniques, 13, 205-218

Kalkstein, A.J., Rudich, Y., Raveh-Rubin, S., Kloog, I., \& Novack, V. (2020). A Closer Look at the Role of the Cyprus Low on Dust Events in the Negev Desert. Atmosphere, 11(10), 1020

Kaplan, G., \& Avdan, Z.Y. (2020). Space-borne air pollution observation from Sentinel-5p

TROPOMI: relationship between pollutants, geographical and demographic data. International Journal of Engineering and Geosciences, 5 (3), 130-137

Kim, H.C., Chai, T., Stein, A., \& Kondragunta, S. (2020). Inverse modeling of fire emissions constrained by smoke plume transport using HYSPLIT dispersion model and geostationary satellite observations. Atmospheric Chemistry and Physics, 20, 10259-10277

Knorr, W., Dentener, F., Lamarque, J.-F., Jiang, L., \& Arneth, A. (2017). Wildfire air pollution hazard during the 21st century. Atmospheric Chemistry and Physics, 17, 9223-9236

Konovalov, I.B., Beekmann, M., Kuznetsova, I.N., Yurova, A., \& Zvyagintsev, A.M. (2011). Atmospheric impacts of the 2010 Russian wildfires: integrating modelling and measurements of an extreme air pollution episode in the Moscow region. Atmospheric Chemistry and Physics, 11, 1003110056

Langmann, B., Duncan, B., Textor, C., Trentmann, J., \& van der Werf, G. R. (2009). Vegetation fire emissions and their impact on air pollution and climate. Atmospheric Environment, 43, 107-116

Lazaridis, M., Latos, M., Aleksandropoulou, V., Hov, O., Papayannis, A., \& Tørseth, K. (2008). Contribution of forest fire emissions to atmospheric pollution in Greece. Air Quality, Atmosphere \& Health, $1,143-158$

Levelt, P.F., Joiner, J., Temminen, J., Veefkind, P., Bhartia, P.K., Zweers, D., Duncan, B.N., Streets, D.G., Eskes, H., van der A, R., McLinden, C., Fioletov, V., Carn, S., de Laat, J., de Land, M., Marchenko, S., McPeters, R., Ziemke, J., Fu, D., Liu, X., Pickering, K., Apituley, A., Abad, G.G., Arola, A., Boersma, F., Miller, C.C., Chance, K., de Graaf, M., Hakkarainen, J., Hassinen, S., Ialongo, I., Kleipool, Q., Krotkov, N., Li, C., Lamsal, L., Newman, P., Nowlan, C., Suleiman, R., Tilstra, L.G., Torres, O., Wang, H. \& Wargan, K. (2018). The Ozone Monitoring Instrument: overview of 14 years in space. Atmospheric Chemistry and Physics, 18, 5699-5745 
Li, Y., Tong, D. Q., Ngan, F., Cohen, M.D., Stein, A. F., Kondragunta, S., Zhang, X., Ichoku, C., Hyer, E.J., \& Kahn, R.A. (2020). Ensemble PM2.5forecasting during the 2018 Camp Fireevent using the HYSPLIT transport and dispersion model. Journal of Geophysical Research: Atmospheres,125, e2020JD032768

Lutsch, E., Strong, K., Jones, D. B. A., Blumenstock, T., Conway, S., Fisher, J. A., Hannigan, J. W., Hase, F., Kasai, Y., Mahieu, E., Makarova, M., Morino, I., Nagahama, T., Notholt, J., Ortega, I., Palm, M., Poberovskii, A. V., Sussmann, R., \& Warneke, T. (2019). Detection and Attribution of Wildfire Pollution in the Arctic and Northern Mid-latitudes using a Network of FTIR Spectrometers and GEOS-Chem. Atmospheric Chemistry and Physics Discussions, https://doi.org/10.5194/acp-2019-881, in review.

Mahura, A., Nuterman, R., Nerobelov, G., Sedeeva, M., Smyshlyaev, S., Savenets, M., Pysarenko, L., Krakovska, S., Ivanov, S., Michaelides, S., Ruban, I., Sassi, A.S., Makkonen, R., Baklanov, A., Petaja, T., Zilitinkevich, S., \& Kulmala, M. (2019). Integrated Multi-Scale Modelling for Meteorology-Chemistry-Aerosol Interactions. Report Series in Aerosol Science, 226, 425-430

Mebust, A.K., Russel, A.R., Hudman, R.C., Valin, L.C. \& Cohen, R.C. (2011) Characterization of wildfire $\mathrm{NO}_{\mathrm{x}}$ emissions using MODIS fire radiative power and OMI tropospheric $\mathrm{NO}_{2}$ columns. Atmospheric Chemistry and Physics, 11, 5839-5851

Rolph, G.D., Ngan, F., \& Draxler, R.R. (2014). Modeling the fallout from stabilized nuclear clouds using the HYSPLIT atmospheric dispersion model. Journal of Environmental Radioactivity, 136, 41-55

Rolph, G., Stein, A., \& Stunder, B. (2017). Real-time Environmental Applications and Display sYstem: READY. Environmental Modelling \& Software, 95, 210-228

Savenets, M., Dvoretska, I., \& Nadtochii, L. (2019). Current state of atmospheric air pollution in Ukraine based on Sentinel-5P satellite data. Visnyk of V. N. Karazin Kharkiv National University, Series “Geology. Geography. Ecology”, 51, 221-233

Schreier, S.F., Richter, A., Schepaschenko, D., Shvidenko, A., Hilboll, A. \& Burrows, J.P. (2015). Differences in satellite-derived NOx emission factors between Eurasian and North American boreal forest fires. Atmospheric Environment, 121. 55-65

Skrynyk, O., Voloshchuk, V., Budak, I., \& Bubin, S. (2019). Regional HYSPLIT simulation of atmospheric transport and deposition of the Chernobyl 137Cs releases. Atmospheric Pollution Research, 10, 1953-1963.
Stein, A.F., Draxler, R.R, Rolph, G.D., Stunder, B.J.B., Cohen, M.D. \& Ngan, F. (2015). NOAA's HYSPLIT atmospheric transport and dispersion modeling system. Bulletin of American Meteorological Society, 96, 2059-2077

Sunar, F., \& Özkan, C. (2001). Forest fire analysis with remote sensing data. International Journal of Remote Sensing, 22:12, 2265-2277

Sundström, A.-M., Karppinen, T., Arola, A., Sogacheva, L., Lindqvist, H., de Leeuw, G., \& Tamminen, J. (2020). Satellite-Based Analysis of Fire Events and Transport of Emissions in the Arctic. EGU General Assembly, EGU2020-18506

Theys, N., Hedelt, P., de Smedt, I., Lerot, C., Yu, H., Vlietinck, J., Pedergnana, M., Arellano, S., Galle, B., Fernandez, D., Carlito, C.J.M., Barrington, C., Taisne, B., Delgado-Granados, H., Loyola, D., \& van Roozendael, M. (2019). Global monitoring of volcanic $\mathrm{SO}_{2}$ degassing with unprecedented resolution from TROPOMI onboard Sentinel-5 Precursor. Scientific Reports, 9, 2643.

Turquety, S., Hurtmans, D., Hadji-Lazaro, J., Coheur, P.-F., Clerbaux, C., Josset, D. \& Tsamalis, S. (2009). Tracking the emission and transport of pollution from wildfires using the IASI CO retrievals: analysis of the summer 2007 Greek fires. Atmospheric Chemistry and Physics, 9, 4897-4913

UNEP Global Environmental Alert Service (GEAS), (2013). Forecasting and early warning of dust storms. February 2013. 14 p.

Verhoelst, T., Compernolle, S., Granville, J., Keppens, A., Pinardi, G., Lambert, J.-C., Eichmann, K.-U., Eskes, H., Niemeijer, S., Fjæraa, A. M., Pazmoni, A., Goutail, F., Pommereau, J.-P., Cede, A., \& Tiefengraber, M. (2020). Quality assessment of two years of Sentinel-5p TROPOMI NO2 data. EGU General Assembly, EGU2020-15036

Voulgarakis, A. \& Field, R.D. (2015). Fire Influences on Atmospheric Composition, Air Quality and Climate. Current Pollution Reports, 1, 70-81.

Wentworth, G.R., Aklilu, Y., Landis, M.S., \& Hsu, Y.M. (2018). Impacts of a large boreal wildfire on ground level atmospheric concentrations of PAHs, VOCs and ozone. Atmospheric Environment, 178, 19-30.

Yurganov, L.N., Rakitin, V., Dzhola, A., August, T., Fokeeva, E., George, M., Gorchakov, G., Grechko, E., Hannon, S., Karpov, A., Ott, L., Semutnikova, E., Shumsky, R., \& Strow, L. (2011). Satellite- and ground-based CO total column observations over 2010 Russian fires: accuracy of top-down estimates based on thermal IR satellite data. Atmospheric Chemistry and Physics, 11, 7925-7942, 2011 
Internet 1: S5P Mission. https://sentinel.esa.int/web/ sentinel/missions/sentinel-5p (16.05.2020)

Internet 2: HYSPLIT model. https://www.ready.noaa. gov/HYSPLIT.php (19.05.2020)
Internet 3: FIRMS (Fire Information for Resource Management System). https://firms.modaps.eosdis. nasa.gov (16.05.2020)

Internet 4: WU (Wyoming University). Atmospheric Soundings: http://weather.uwyo.edu/upperair/ sounding.html (18.05.2020)

\section{Appendix A}

Directions of burning products transportation from active fires during 8-13 April based on HYSPLIT ensemble trajectories
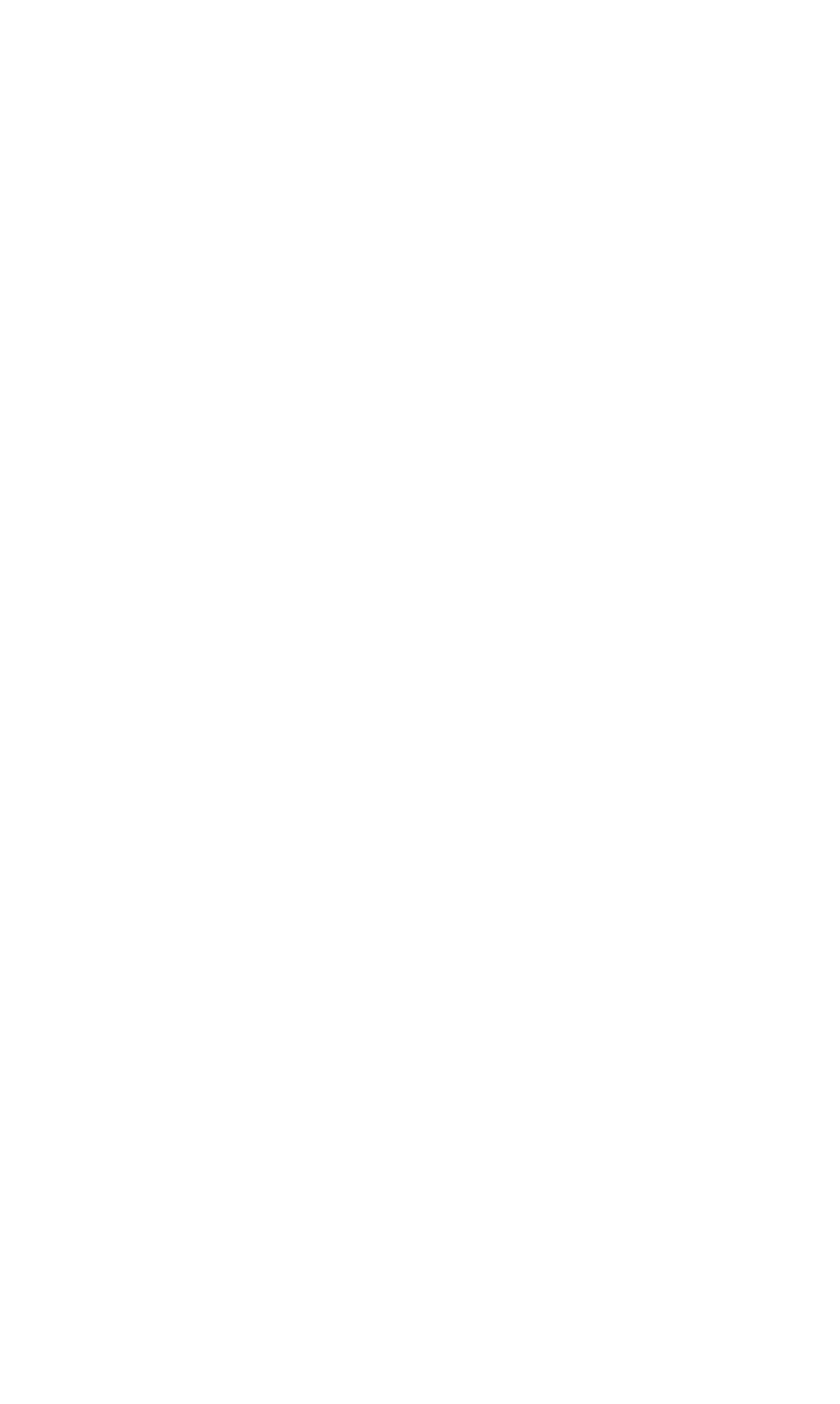

NOAA HYSPLIT MODEL
Forward trajectories starting at 0000 UTC 13 Apr 20

GFSQ Meteorological Data

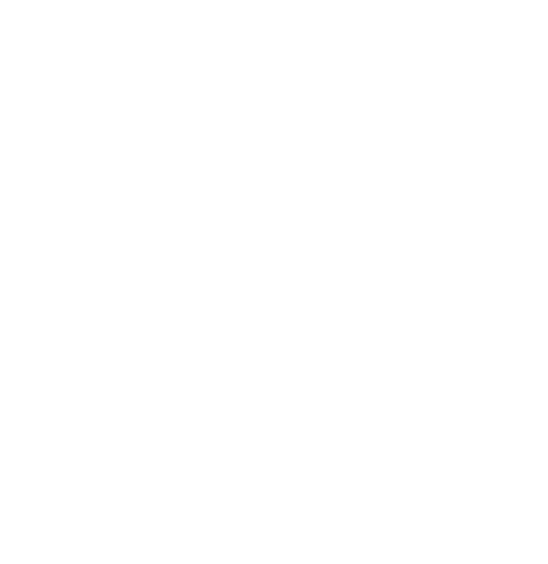




\section{Appendix B}

Directions of burning products transportation from active fires during 16-19 April based on HYSPLIT ensemble trajectories

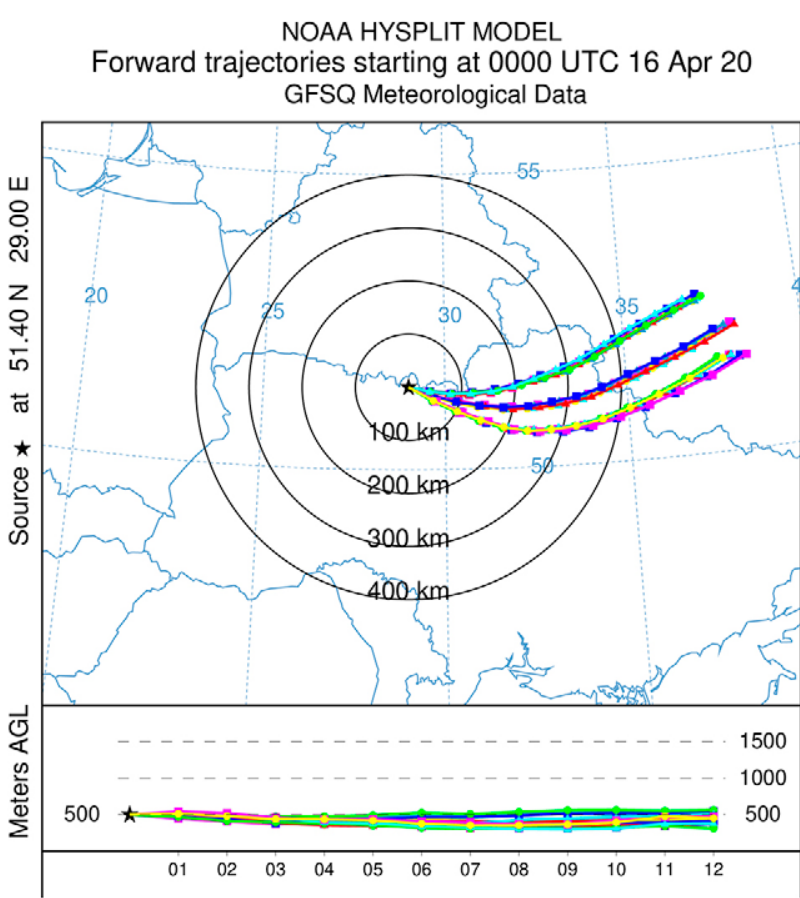

NOAA HYSPLIT MODEL

Forward trajectories starting at 0000 UTC 18 Apr 20 GFSQ Meteorological Data

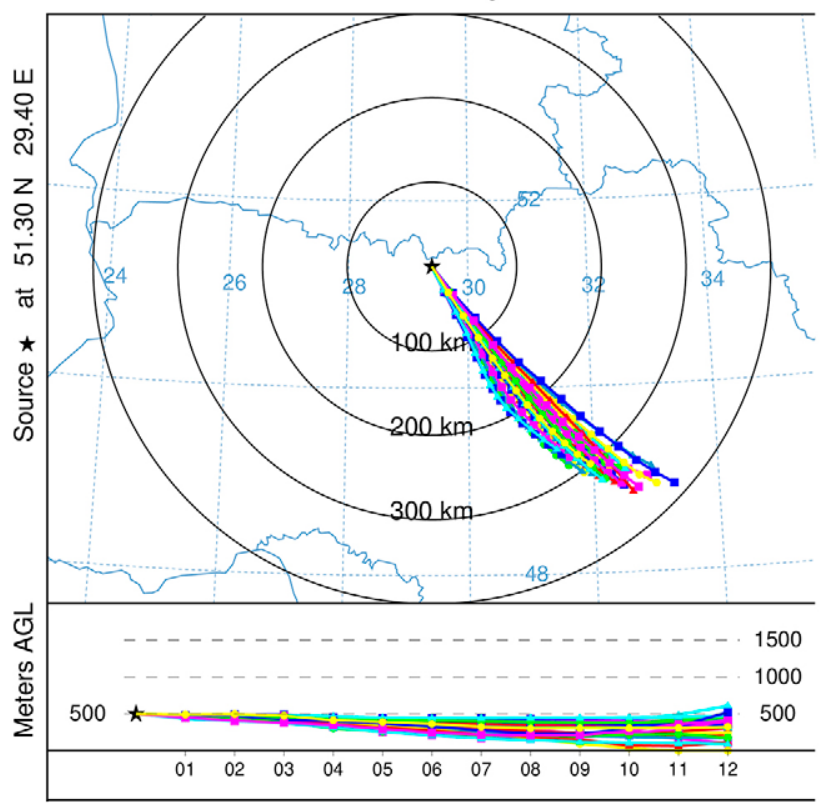

NOAA HYSPLIT MODEL

Forward trajectories starting at 0000 UTC 17 Apr 20 GFSQ Meteorological Data

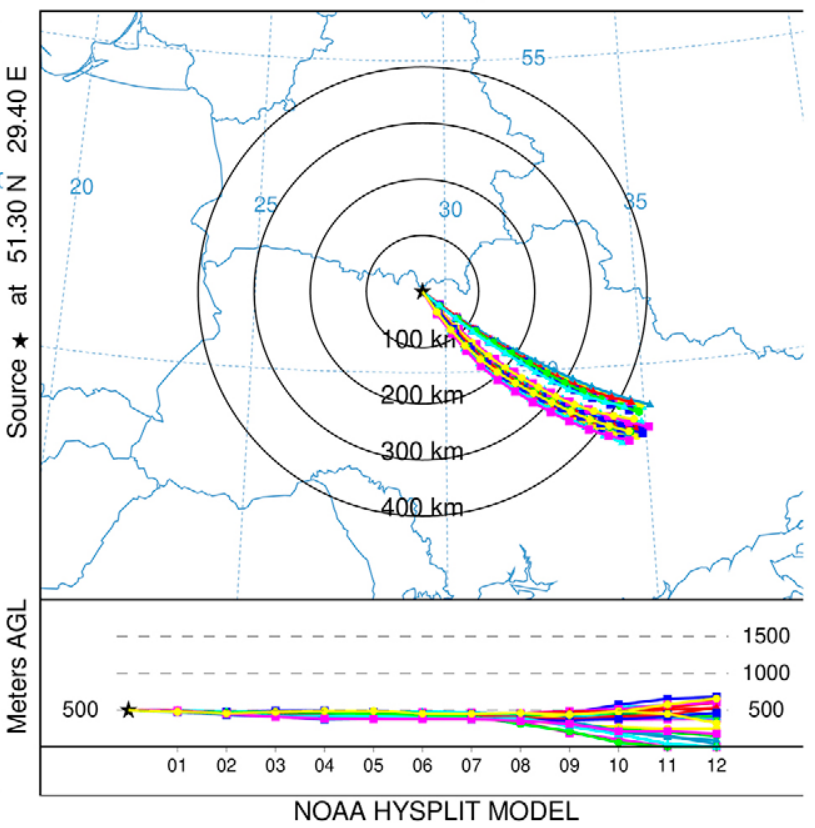

Forward trajectories starting at 0000 UTC 19 Apr 20

GFSQ Meteorological Data

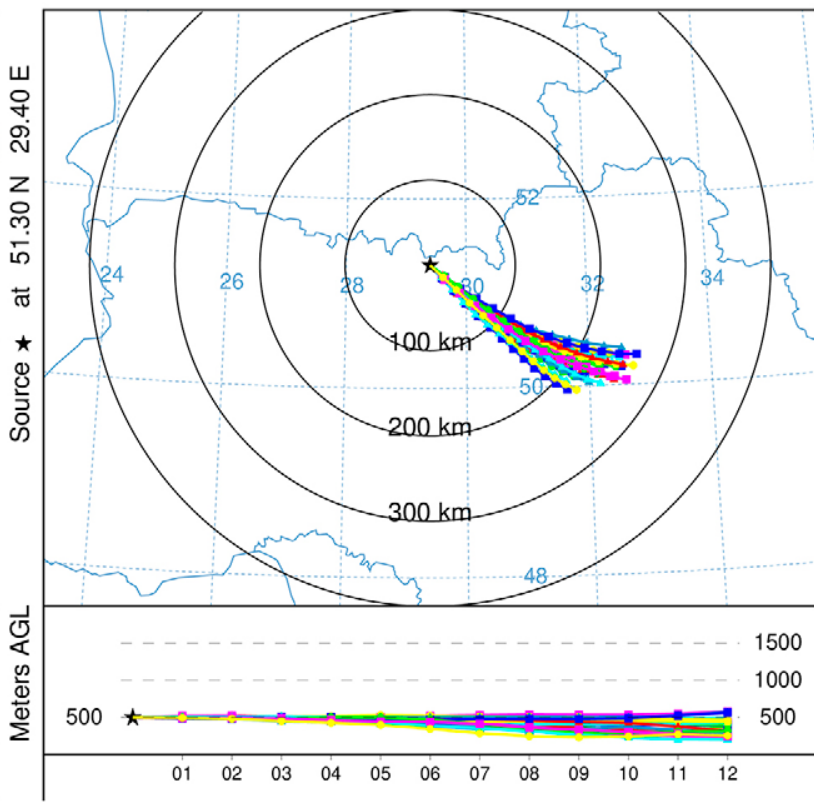

